\title{
CEO Perquisites in Canada, 1971-2008: Certainly Not Pure Managerial Excess
}

\author{
Patrice Gélinas $^{1} \&$ Lisa Baillargeon ${ }^{2}$ \\ ${ }^{1}$ School of Administrative Studies, York University, Toronto, Canada \\ ${ }^{2}$ École des Sciences de la Gestion (ESG-UQAM), Montreal, Canada \\ Correspondence: Patrice Gélinas, School of Administrative Studies, York University, 4700 Keele Street, \\ Atkinson Building, Office 254, Toronto, ON, M3J 1P3 Canada. E-mail: gelinas@yorku.ca
}

Received: February 25, 2018

Accepted: March 23, 2018

Online Published: April 18, 2018

doi:10.5539/ijbm.v13n5p105

URL: https://doi.org/10.5539/ijbm.v13n5p105

\begin{abstract}
This paper explores Canadian market data on CEO perquisites gathered by a large consulting firm over the period from 1971 to 2008. Perquisites are one of the least documented total compensation components in the academic literature on executive pay. Scant existing literature may be due to the relatively recent and limited corporate disclosures on CEO perquisites, as well as to the comparatively modest monetary value of perquisites relative to other total CEO compensation components. Meanwhile, CEO perquisites regularly capture the public's imagination in the media because of some perceived excesses, such as immoderate personal use of corporate aircraft (see Rajan \& Wulf, 2006). We document a significant evolution in CEO perquisites practices over the period. Consistent with a nascent body of literature, this paper supports empirically hypotheses arguing that CEO perquisites do not uniquely occur as a result of an agency problem, the main theoretical explanation for their existence as of yet, but that they can also serve a legitimate, value-creating, business purpose for the benefit of shareholders.
\end{abstract}

Keywords: executive perquisites, CEO compensation, agency theory

\section{Introduction}

Typical perquisites (perks) provided to Canadian CEOs include company-provided vehicles, sport and business club memberships, tax and financial planning services, as well as an array of other executive-only benefits. The most widespread academic view on perks, originating from the analyses of Jensen and Meckling (1976), is that they epitomize agency problems because they are a way managers can divert firm resources from shareholders to their private benefit. One of the main arguments against perks is the difficulty for outsiders to measure their value since it is characteristically underreported to shareholders, when disclosed (Grossman \& Hart; 1980; Jensen \& Meckling, 1976; Jensen, 1986). The timing of these seminal agency-based studies matches the late 70's ire of the US Congress and President Carter over companies taking tax deductions for lavish lunches and subsidies, which appeared as a result of the stagnant stock market's inability to produce managerial compensation in line with expectations (Murphy, 2011).

A more timid and recent alternative theoretical view on perks contends that perks can represent a wise compensation spend for the firm because the benefits to shareholders exceed the perquisite costs (e.g., see Siming, 2016). From a business standpoint, perks are often viewed as possibly tax-effective or beneficial to the shareholders as they can be designed to improve the health and wellbeing of the recipient. Whether perks are necessarily the result of managerial excesses remains an empirical debate.

To shed some empirical light on this debate, this paper explores Canadian market data on CEO perquisites gathered by a large consulting firm over the period from 1971 to 2008. Perquisites are one of the least documented total compensation components in the academic literature on executive pay. Scant existing literature may be due to the relatively recent and limited corporate disclosures on CEO perquisites (SEC, 2006; CSA, 2008), as well as to the comparatively modest monetary value of perquisites relative to other total CEO compensation components. These two constraints limit the ability to carry mainstream market-based research couched in the agency paradigm, such as that of Yermack (2006). Meanwhile, CEO perquisites regularly capture the public's imagination in the media because of some perceived excesses, such as immoderate personal use of 
corporate aircraft (Rajan \& Wulf, 2006). The objectives of this paper are therefore to provide an explorative historical account of the evolution of CEO perquisites practices in Canada over the period 1971-2008, and to assess whether perks are uniquely the product of agency problems or if they can also be wise compensation investments made by, or on behalf of, shareholders.

\section{Literature Review and Hypotheses}

The widespread agency-based theoretical view on perks can be traced back to Jensen and Meckling (1976), Fama (1980), and Jensen (1986), who all contend that perks can be explained by the ability of managers to extract resources from the firm for their private benefit. Alternative views are that perks can be a wise compensation investment either because they have a perceived value which far exceeds their cost or because they are a tax-effective compensation vehicle (see Rajan \& Wulf, 2005; Siming, 2016). Andrews \& al. (2009) even argue that good practices relative to perks are important to reduce the agency problem.

The empirical literature on CEO perquisites practices in Canada is quite limited while literature on executive compensation is richly documented (e.g., Craighead, Magnan \& Thorne, 2004; Gélinas, Magnan \& St-Onge, 2009; Magnan St-Onge \& Thorne, 1996; Zhou 1999 \& 2000; Zhou \& Swan, 2003). Recent and limited disclosure related to perquisites may explain the scarcity. It is only in 2006 that the Security and Exchange Commission (SEC) proposed amendments in order to upgrade transparency on the current disclosure on benefits and perquisites which would be required for firms to comply in 2007 (Note 1). An entirely new disclosure section called "Compensation Discussion and Analysis" ("CD\&A") would be then required. In summary:

"The SEC's new disclosure rules forced companies to provide an unprecedented amount of detail on the nature and value of executive benefits and perquisites in 2007, and, as a result, executive perquisites remain in the spotlight." (Equilar, 2007:2)

Further,

"SEC indicated that a reportable perquisite confers on an executive a direct or indirect benefit with a personal aspect, is not directly related to the performance of the executive's duties, and is generally not offered to all employees." (Liu \& Yin, 2011)

Few studies found before 2006 on perquisites regulation in United States are mainly analyzing the impact of SEC 1978 disclosure regulation on management perquisites (McGarhan, 1988). The studies explore the shift from perquisites to monetary benefits following the new regulation while not eliminating perks. From 2006, literature found on perquisites mainly focuses on perks' effects on firm value. Yermack (2006), for instance, focused on the uncovering mismanagements of perks and its detrimental consequences on the value of the firm through an analysis of the use of corporate jets by business executives, a relatively rare and expensive perk which makes the generalizability of findings questionable.

In Canada, literature on perquisites is even more limited than it is in the US. The new Canadian rules on perquisites disclosure was adopted by the Canadian Securities Administrators (CSA) in September 2008 following the 2006 changes in the US, with some dissimilarity (MacDougall \& Lurie, 2008). In terms of perquisites,

"The executive compensation disclosure rules now include guidance on the determination and valuation of perquisites for reporting purposes. A benefit that is integrally and directly related to the performance of the executive's duties is not a perquisite even if it provides some personal benefit. However, if the benefit is not integrally and directly related to the performance of the executive's duties, it is a perquisite unless (i) there is no direct or indirect personal benefit or (ii) it is generally available on a non-discriminatory basis to all employees. The de minimus threshold for determining when perquisite disclosure may be omitted from the Summary Compensation Table has been reduced to the lower of Cdn\$50,000 and 10\% of total salary from the lower of Cdn\$50,000 and 10\% of total salary plus bonus." (MacDougall \& Lurie, 2008)

The somewhat limited academic literature on perquisites and the evolution of disclosure regulation make it unambiguous that there have been excesses as predicted by the agency theory. However, the persistence of perquisites as a regular component of total CEO compensation despite regulation to curb excesses suggests implicitly that some perquisites serve a legitimate business purpose. Siming (2016) suggests that one of those possible purposes is that perquisites convey status cheaply. Hence the following hypothesis:

H1: CEO perquisites offered in Canada can function as a status-conveying signal representing a relatively modest cost to the company relative to the compensatory value perceived by the CEO.

Also consistent with the literature, we believe there is a possibility of identifying perquisites which can clearly 
be identified as productivity enhancers and be discarded as the outcome of agency failures due either to their limited appeal or monetary value. Consequently, we hypothesize that:

H2: CEO perquisites offered in Canada can function as a value-adding productivity enabler.

Finally, the evolution of disclosure regulation leads one to believe that boards of directors became far more aware of their obligation to manage perquisites responsibly over time. This would have led to reducing the uncertainty regarding the value of perquisites provided to executives. We consequently hypothesize:

H3: The compensatory value of CEO perquisites in Canada has been managed increasingly tightly by boards of directors over time.

\section{Data Source and Method}

The 2008 disclosure rules on perquisites were made effective in Canada the same year our database ends. Our study consequently explores perquisite practices pre-dating the 2008 changes in Canadian disclosure regulation which has made the value of perquisites over a threshold disclosable to the public.

Our database also includes data which predates the US 1978 Disclosure Rules on executive compensation. It is important because the US 1978 Disclosure Rules almost certainly had an effect on the practices of companies in our database because many of them were Canadian branches of multinational US corporations (e.g., Canadian General Electric Co. Ltd.). Indeed, it is almost certain that perk policies at the parent organization had an important influence on the practices of foreign subsidiaries.

We analyze the prevalence of CEO perquisites in Canada over the studied period, as reported in the annual executive compensation survey report of a large and reputable consulting firm. This source is unique and unavailable to the public. The 38-year span of the study provides a unique longitudinal view of the survey-based information available to boards of directors when making executive perquisite decisions.

\section{Methodology}

From a methodological standpoint, we started this explorative research with an intrusive scan of the evolution of perquisites prevalence in Canada over the years. We gathered statistics on perquisites from market data published in the annual Canadian executive compensation survey of a large and reputable consultancy firm from 1971 to 2008. This source is unique and unavailable to the public. For each year, we recorded all available data on the perquisites categories and the changes over time as well as the percentage of CEOs benefiting from each form of compensation. Prevalence by organizational size was also possible starting from the 1990s'.

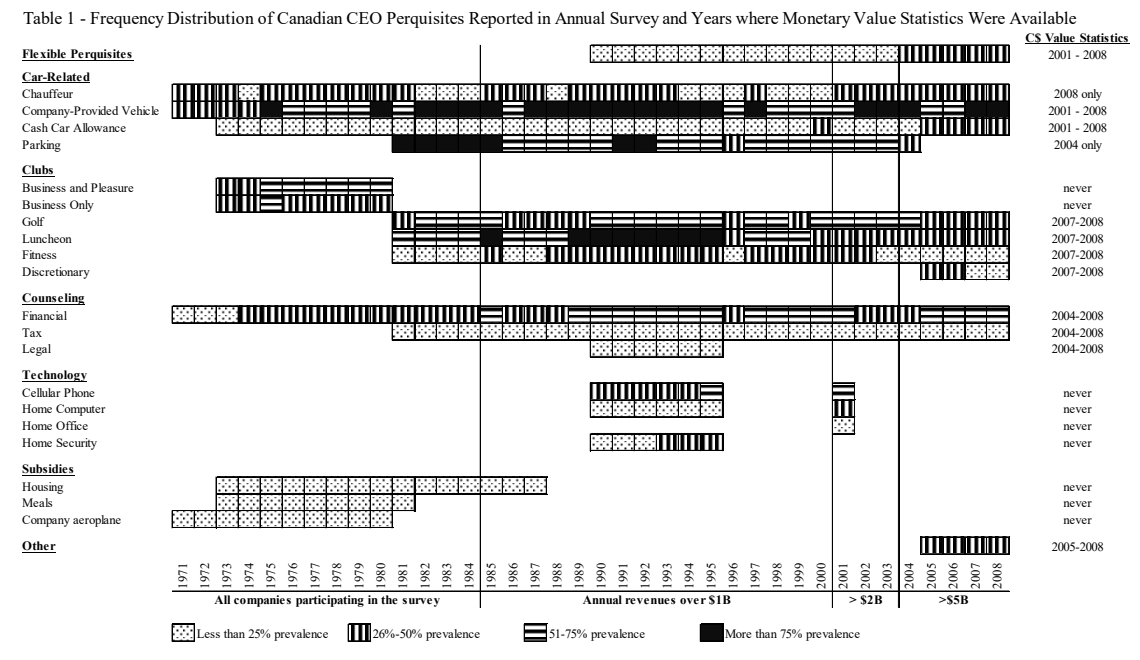

One non-negligible weakness of the data source base is that we do not have access to company-specific perquisite practices, but rather only to prevalence data and, from 2001 and on, statistics on the value of perks. Consequently, the span of analyses we can perform is far more limited. Nevertheless, our analytical strategy to accept or reject our hypotheses is to find, within the available dataset, as much information as possible which unambiguously supports our hypotheses while being implausible with rival hypotheses. Table 1 summarizes the information on CEO perquisites made available to us for years 1971 to 2008. 


\section{Findings}

Table 1 shows that the list of perquisites offered over time has evolved. While some CEO perquisites have ceased to be prevalent enough to be recorded over time, such as subsidized meals, subsidized housing and sabbatical leaves, new forms of perquisites have emerged over time, such as flexible perquisites and tax counseling. Car perquisites, clubs and financial planning were reported throughout the studied period. Finally, some technology-related perquisites such as cell phone, home computer and home security came and went as those technologies ceased to represent executive privileges.

\subsection{Consistent with $\mathrm{HI}$}

To find support for $\mathrm{H} 1$, we should observe prevalence of perquisites of modest or negligible monetary value and which are generally available exclusively to senior executives and not to the "common worker". A persistent perk fitting these criteria is the company parking. It can be argued that company-provided reserved parking spots serve a business purpose, as they can ensure the CEO wastes no time looking for a parking spot, or that they reflect a misappropriation of company resources. However, these views would not be totally consistent with the quite widespread practice of making individualized reserved parking spots very ostensibly identified and with the executives' names, with the proximity to the main entrance consistent with the hierarchical rank of the beneficiary. In many cases, such as when the employer owns a parking lot, the reservation of specific spaces for the senior leadership team comes at no additional cost while it communicates the organizational hierarchy to all workers and visitors. We conclude that the persistence of company-provided parking perquisites through all years the survey recorded this perquisite provides support for H1. See Morand and Merriman (2011) for a theoretical explanation of the diminishing prevalence of such differential perquisites, also observable in Table 1.

A similar analysis can be made of the company-provided cellular phone in the early $90 \mathrm{~s}$. Whereas it may certainly have served a business purpose, it was also very ostensible at the time. And it certainly never represented disproportionately expensive perquisite for a $\$ 1$ billion+ company CEO. An interesting twist is that company-provided cellular phones ceased to be perceived as a perquisite when they became accessible to a much larger fraction of the population after 2001. The rise of the company-provided cellular phone when it was perceived as an exclusive privilege and its fall after cellular phones became available to the masses also provides support for $\mathrm{H} 1$.

\subsection{Consistent with $\mathrm{H} 2$}

To find support for $\mathrm{H} 2$, we should find perquisites which persist despite market and regulatory conditions. Perquisites have had significant bad press, often for good reasons (see Fisher, 2012), progressively more stringent tax treatments (see Saez, 2006, for a historical discussion), and have been subjected to increasing disclosure regulation in order to limit their abuse by management. In this increasingly hostile context, the prevalence of some perquisites, such as clubs and subsidies has decreased over time while the prevalence of others, such as company-provided vehicles and financial counselling, has persisted. The usual justification for company-provided vehicles is that they ensure executives use a car which preserves the image of the organization while allowing them to focus on their job as opposed to car maintenance chores. The usual justification for providing financial counselling to an executive is that the job requirements create a very complex personal finance situation. For instance, executives are often required to concentrate a disproportionate proportion of their wealth in the stock of their employer. Also, the CEO position may require working in several jurisdictions each year, which may create extraordinarily complex tax obligations that a CEO should not have time to worry about. Also, the company has no interest in having negative publicity should one of its top executives possibly have very public problems with tax authorities due to oversight or incompetence in self-completing income tax reports. Whereas we cannot completely rule out the agency problem argument, the persistence of company-provided vehicles and financial counselling over time provides support for $\mathrm{H} 2$.

Another indication consistent with $\mathrm{H} 2$ is that the value of company-provided vehicles and financial counselling is in most cases below the disclosure regulation thresholds for detailed disclosure, an implicit sign that they may not be abusive but rather useful for executives and shareholders alike.

\subsection{Consistent with $\mathrm{H3}$}

To find support for H3, we should find indications that the compensatory value of perquisites is managed increasingly tightly over time, or signs that the most indefensibly lavish perquisites are disappearing over time, and especially following the implementation disclosure regulation pursuing this goal.

Our data provides ample support for H3. A first indication that boards manage the compensatory value of perquisites more tightly over time is the appearance of monetary value in the survey data in 2001 , which must be 
the result of a certain demand since participants, as customers and purchasers of the survey, had a say in its design. The appearance of monetary value statistics is consistent with a realization by boards that perquisites are part of an executive's total compensation and that a company's spending on perquisites should be managed as a meaningful expense. This provides strong support for $\mathrm{H} 3$.

Also consistent with $\mathrm{H} 3$ is the emergence and prevalence growth of flexible perquisites. Flexible perquisites usually provide executives with a predetermined perquisites budget which may be spent on a selection of allowable or available company-sponsored perquisites, with any unspent budget usually paid in cash. The monetary value of each perquisite is then very clear and it is straightforward for boards to understand the compensatory value of the perquisites they provide. A number of companies make a preselection of perquisites mandatory in their flexible perquisites program, a feature consistent with $\mathrm{H} 2$.

The prevalence of subsidies in the early 70s and their progressive disappearance after 1978 is very consistent with the goal of the 1978 US Disclosure Rules (see Murphy, 2012). It is also consistent with H3 for two reasons. First, the 1978 Rules are the result of a very public outcry regarding executive perquisite excesses. It is therefore plausible that such publicity should have focused boards of directors' attention to perquisites, leading to a tighter management and the elimination of hard-to-justify subsidies. Second, the virtual extinction of subsidies by 1988 , 10 years after the implementation of 1978 US Rules, is (at least visually in Table 1) tied to a change in the Canadian approach to perquisites and probably synched with the CEO turnover of those who were grandfathered subsidy perquisites by the most complacent boards. We note that the disappearance of subsidies surely gives credibility to the claim that perquisites may have been the result of agency problems, at least in the 70s. Nevertheless, their progressive disappearance, coupled with the emergence of new perquisites, especially those which can be valued unambiguously, gives credibility to the alternate viewpoint that perks may be managed to add value for shareholders.

The gradual disappearance of club perquisites, especially those not clearly serving a business purpose (e.g., fitness, discretionary), is also consistent with $\mathrm{H} 3$. We cannot rule out however that the disappearance of club perquisites may be linked to the evolution in the way of doing business. If such were the case however, their disappearance would be consistent with $\mathrm{H} 2$.

Finally, the disappearance of company aeroplane perquisites over time is also consistent with $\mathrm{H} 3$ since it is a perquisite associated with agency problems (Yermack, 2006).

\section{Conclusion}

The main finding of this paper is that CEO perquisites are not uniquely the product of agency problems. They can also be a compensation vehicle beneficial to shareholders, either because they serve a business purpose or because they carry a status-conveying value for CEOs. In the latter case, the monetary cost of replacing some perquisites' status-conveying value with other forms of compensation carrying less status-conveying value per company dollar spent would be higher and, thus, value-destroying.

While we acknowledge that there may be agency problems associated with perquisites, our findings indicate that agency problems seem to have decreased over time, as boards of directors managed perquisites increasingly as a component of CEOs' total compensation, with the help of pressure originating, at least in part, from disclosure regulation.

The study has some limitations. We rely on a rich database providing mainly annual prevalence data. We did not have the possibility of designing empirical tests where we could have analyzed company-specific practices could have been even more conclusive. We also rely on a very rich, but nevertheless unique and only Canadian, data source, which makes the generalizability of data less certain. Many of our conclusions are based on the assumption that perquisites were recorded in years where their actual prevalence was measurable. While very reasonable, this is a working assumption that is not verifiable. Despite these limitations, we remain confident that they do not make our broad findings questionable.

There is ample room for future research. This study focuses on CEO perquisites. Comparisons between CEOs and non-CEO executives could provide further and more precise support for our hypotheses. Our data could be further analyzed in conjunction with the evolution of tax rules, of direct CEO compensation, of disclosure regulation, of shareholder activism, of governance and of the public's perception of perquisites. Finally, our approach acknowledging that there have been agency-related problems with perquisites, but that there are other coexisting explanations could be promising in other research settings.

\section{References}

Andrews, A., Linn, S., \& Yi, H. (2009). Corporate governance and executive perquisites: evidence from the new 
SEC disclosure rules. AAA 2009 Financial Accounting and Reporting Section (FARS) Paper. March.

Craighead, J. A., Magnan, M. L., \& Thorne, L. (2004). The Impact of Mandated Disclosure on Performance-Based CEO Compensation. Contemporary Accounting Research, 21(2), 369-398. https://doi.org/10.1506/bpcx-d3fc-y8vy-m541

Equilar (2007), CEO Benefits \& Perquisites Report.

Fama, E. (1980). Agency problems and the theory of the firm. The Journal of Political Economy, (2), 288-307. https://doi.org/10.1086/260866

Fisher, D. (2012), The Most Outrageous Executive Perks. Forbes. https://doi.org/10.1093/ww/9780199540884.013.10000485

Gélinas, P., Magnan, M., \& St-Onge, S. (2009). CEO target compensation and performance standards in privately-and publicly-held firms through a disclosure regulation change. International Journal of Business Governance and Ethics, 4(3), 222-249. https://doi.org/10.1504/ijbge.2009.023330

Grossman, S. J., \& Hart, O. D. (1980). Disclosure laws and takeover bids. The Journal of Finance, 35(2), 323-334. https://doi.org/10.1111/j.1540-6261.1980.tb02161.x

Jensen, M. C. (1986). Agency costs of free cash flow, corporate finance, and takeovers. The American Economic Review, 76(2), 323-329. https://doi.org/10.1017/cbo9780511609435.005

Jensen, M. C., \& Meckling, W. H. (1976). Theory of the firm: Managerial behavior, agency costs and ownership structure. Journal of financial economics, 3(4), 305-360. https://doi.org/10.1016/0304-405x(76)90026-x

Liu, H., \& Yin, J. (2011). Executive perquisites, excess compensation, and pay for performance. Journal of Academy of Business and Economics, 11(3).

MacDougall, A., \& Lurie, J. (2008). New executive compensation disclosure rules affect issuers with year ends on or after December 31. Osler, Hoskin \& Harcourt LLP, October. Retrieved from http://www.mondaq.com/canada/x/68738/Directors+Officers/New+Executive+Compensation+Disclosure+ Rules+Affect+Issuers+With+Year+Ends+On+Or+After+December $+31+2008$

Magnan, M., St-Onge, S., \& Thome, L. (1996), Performance organisationnelle et rémunération des dirigeants: une comparaison Canada - états-Unis. Canadian Journal of Administrative Sciences / Revue Canadienne des Sciences de l'Administration, 13, 102-118. https://doi.org/10.1111/j.1936-4490.1996.tb00108.x

McGahran, K. T. (1988). SEC disclosure regulation and management perquisites. Accounting Review, 63(1), 23-41.

Morand, D. A., \& Merriman, K. K. (2012). "Equality theory" as a counterbalance to equity theory in human resource management. Journal of Business Ethics, 111(1), 133-144. https://doi.org/10.1007/s10551-012-1435-y

Murphy, K. J. (2012). The politics of pay: A legislative history of executive compensation. Research Handbook on Executive Pay, 11-40. https://doi.org/10.4337/9781781005101.00007

Rajan, R. G., \& Wulf, J. (2006). Are perks purely managerial excess?. Journal of Financial Economics, 79(1), 1-33. https://doi.org/10.1016/j.jfineco.2005.01.003

Saez, E. (2006). Income concentration in a historical and international perspective. A. Auerbach, D. Card, and J. Quigley (Eds.), Public Policy and Income Distribution. https://doi.org/10.3386/w11955

Siming, L. (2016). Orders of merit and CEO compensation: Evidence from a natural experiment. Corporate Governance: An International Review, 24(1), 64-78. https://doi.org/10.1111/corg.12118

Yermack, D. (2006). Flights of fancy: Corporate jets, CEO perquisites, and inferior shareholder returns. Journal of Financial Economics, 80(1), 211-242. https://doi.org/10.1016/j.jfineco.2005.05.002

Zhou, X. (1999). CEO target compensation and performance standards in privately- and publicly-held firms through a disclosure regulation change. Journal of Corporate Finance, 5(3), 277-301.

Zhou, X. (2000). CEO pay, firm size, and corporate performance: Evidence from Canada. Canadian Journal of Economics/Revue canadienne d'économique, 33(1), 213-251. https://doi.org/10.1111/0008-4085.00013

Zhou, X., \& Swan, P. L. (2003). Performance thresholds in managerial incentive contracts. The Journal of Business, 76(4), 665-696. https://doi.org/10.1086/377035 


\section{Note}

Note 1. This amendment enforces the 1978 SEC regulation that required companies to disclose the dollar value of perquisites consumed by their executives. Before 1978, perquisites were not considered as compensation but as business expenses. (McGahran, SEC Disclosure and Management Persquisites, p. 1)

\section{Copyrights}

Copyright for this article is retained by the author(s), with first publication rights granted to the journal.

This is an open-access article distributed under the terms and conditions of the Creative Commons Attribution license (http://creativecommons.org/licenses/by/4.0/). 